\title{
Ways Used by EFL Learners to Improve their English Pronunciation
}

\author{
Abeer AL-Ghazo \\ Assistant Professor \\ Ajloun National University \\ Mahmoud Al-Sobh \\ Associate Professor \\ Ajloun National University \\ Rana Momani \\ Ajloun National University
}

\begin{abstract}
This study aimed at investigating ways used by EFL learners to improve their English Pronunciation at Ajloun National University. In this study, the researchers used Quantitative research design. They used a questionnaire as an instrument to collect data then they analyzed these data by using statistical package for social sciences (SPSS) , " $t$ "test and ANOVA. The results of the first question showed that the overall degree of that was used by EFL learners to improve their pronunciation is high.The learners' responses to most of the items in the questionnaire showed their high positive use of different ways towards learning the correct pronunciation.
\end{abstract}

Keywords: pronunciation, oral proficiency, ANU

\section{Introduction}

\section{Background of the Study}

English is considered as one of the most important international languages as a means of communication as it is used indifferent sectors in the world. English is taught for twelve years, from the first grade to the twelfth grade in many different locations in this world, in the public as well as the private schools. To achieve the goal of learning English, learners should master the four English language skills to master English. When learners learn a foreign language, they usually learn to listen, first, then to speak, read, and finally write.

Ministry of Education (2006, p.9) stated that: "English is an international language and fundamental to learning and communicating in all cultures with the increasing amount of information and communication technology... Through learning English, the students will be able to develop confidence, competence and self reliance to meet the demands of development and further education".

Speaking, as an English skill, is considered as one of the most crucial skills as it is a process that helps in improving student's oral proficiency. Speaking is one of the most important skills among the other four language skills. It should be taught to be developed as a means of effective communication in both first and second language learning context in Jordanian Universities, particularly at Ajloun National University. In this context, Osborn, et al (2008) indicated that "effective communication by mean of speaking usually creates a number of benefits for both speakers and learners for example effective speaking skill results in achievements during ceremonial speaking activities, job training, activities, job interview, and other business purposes. We can say any person without oral communication skills will suffer in this era of competition and may find it difficult to achieve a higher position". Before you learn how to speak the language, you need to learn how to listen. Some sounds can be hard to be understood when you hear them. For example, let us study the following examples: Did the speaker sleep or slip? Did he hurt his chin or his shin? If you can hear the differences among these sounds, it will be easier to communicate and use the language as speaking is considered as a productive skill that help sits users to communicate with others to express their thoughts and ideas easily and freely. Despite its importance, it is stated that it is the most difficult skill that learners face many difficulties in mastering it. 
Li (2003) stated that mastering English oral proficiency is still the most difficult skill for the majority of English foreign learners. To speak very well, you have to pronounce English words very well. Students face many difficulties in learning English, they do not feel confidence enough to speak English with their teachers as well as their classmates. They do not have the opportunities to communicate with native speakers to pronounce words correctly or to have a fluent conversation with them. Lack of using videos, listening to authentic contexts, or having English pen friends, for example, stand against the students' progress in learning English.

To what extent is it possible to make learners understand the importance of pronunciation is an important key to speak English correctly in particular and in learning English as a foreign language in general? This is a key question that concern many scholars in education. Nobody could ignore the importance of speaking as a vital skill in learning English. The teaching of speaking has become increasingly important in English as a foreign language (EFL) context due to its importance in expressing one's thoughts, ideas and opinions about different issues in our life. To support this point of view, let us consider what Baxter stated in 1954 :

"We live in an age when one of the basic requirements for success in any field is the ability to speak well.Those who take the trouble to master the art of speaking are usually persons of influence and power." (p.1)

Pourhosein (2012) concludes that the limited pronunciation skills has many negatives in the learner's learning journey to learn English as it can affect students' self-confidence, restrict their social interactions , and thus negatively it may affect estimations of learners' abilities. Jones (2002) indicated "pronunciation teaching methods should address the issues of motivation and exposure by creating awareness and stressing the importance of sound pronunciation".

Bashiruddin, (2003) conducted a study to improve student's Oral Communication Skills (OCSs) in lower secondary public school in Karachi, Pakistan. The sample of the study consisted of two schools systems - the government Urdu-medium school and the private English medium school- work side by side. Is. English is learnt as a second language in both cases. Both students' and teachers use Urdu language or the regional language to communicate inside the class, and practice traditional methods which focus on reading and writing skills, but productive skills such as: speaking is given on important. The results of the study discussed the reasons of weakness of students in communication were the English language teachers (ELTs) are not proficient in speaking English and this is the main obstacle in the way to teaching English in Pakistan.

Urrutia, \& Vega (2006) conducted an action research project on understanding and actions taken to develop speaking skills through games in one of the public school which called "Federico García Lorca" in Colombia. The sample in this study was twenty girls and twenty boys from 14 to 18 years old. Questionnaires, teacher's journals and video recordings were used as data collection instruments. The results of the study revealed that the majority of students considered that speaking is the most complicated ability to work out; also, the researchers noticed that students sometimes spoke English, but the majority of them did not speak during the English class.

Rama, Ying, lee \&Luei (2007) conducted an action research study on the hypothesis of using language games to improve speech skills during English classes in a primary school called "Jurong" in Singapore. The participants in this study were 78 students. The researchers used two different methods for two different groups; they divided students into experimental group in which was implemented a communicative method where language games were implemented to improve speaking skills, and a control group which was focused in a teacher centered method in which teachers used real- life activities including the essential vocabulary to perform a conversation. The results of the study organized in two tables. The first table shows the study of pretests and post-tests where 4 students did not were present in class during the pre-test and a total of 35 students were present in pre-test and post-test.

Hamzah \& Umehara (2010) tried to examine the difficulties in pronouncing English among the participants (four Japanese adult English learners) in this study. Moreover they tried to assess the improvement in the participants' spoken English, after undergoing a 'shadowing' technique. The participants in this study are four retired Japanese adult learners who are currently staying in Malaysia as their second home. They were born in Japan, and their mother tongue is Japanese. They graduated from various universities in Japan almost forty years ago and had not attended any formal English Language course since. The results revealed that every learner appeared to have improved in their speech rhythm through shadowing. Some of them were able to follow almost all the sentences with exception of long and difficult ones. 
They tried really hard to reproduce speech sounds just as they heard them so that their speech sounded natural. Consequently, they could understand the sound heard without translating it into Japanese. NuriaEdoMarzá (2014) investigated students' perceptions for improving and enhancing Spanish EFL learners' pronunciation comprehension. The researcher designed three questionnaires to analyze the data. A diagnostic analysis was carried out. The results revealed that learners' motivation and implication were high when pronunciation being taught. They believe that implementing pronunciation instruction is useful.

Hassan (2014) investigated the main problems faced learners who speak Arabic. In order to improve their English pronunciation, learners find some effective strategies and techniques. The participants of the study were fifty students from University of Sudan of Science and Technology (SUST), and thirty university teachers of English language from the same university. The researcher used observation, recordings and a structured questionnaire as instruments to collect the data. Then the data were analyzed descriptively and statistically. The findings revealed that Sudanese students of English had problems with the pronunciation of English vowels.

Omer \& Khan (2015) investigate the main difficulties encountered by Saudi learners at secondary schools when they pronounce English consonants. It also tries to investigate the area of English consonant clusters system. The researchers used a questionnaire, classroom observation and document collections to collect the data. The results revealed that learners had difficulties to pronounce eleven consonant sounds. The results also indicate that a great number of the students, unintentionally insert a vowel sound in English syllable to break up consonant clusters

\section{Statement of the Problem}

As a student at ANU, the researchers have noticed that the majority of students are unable to communicate through using English in a proper way. They have noticed through their communication with their students that the students are not trained and prepared well to pronounce and speak English at class and outside the class. Consequently, when students are asked to participate in doing the classroom's exercises, they hesitate. They do not like to participate in these activities due to many reasons, such as lack of confidence, lack of their linguistic and oral proficiency or their negative image about themselves. All these reason and other reasons stand against any kind of progress in learning English despite its importance as a language that all people as well as students seek to master. Pronunciation is a major problematic aspect for most EFL learners. In fact, the reasons behind these difficulties and solutions may be varied in their nature and in effectiveness. Traditionally, most EFL teachers tend to neglect teaching of pronunciation in EFL settings and classes, focusing instead of that on other skills and language aspects, such as reading, writing, listening and speaking. In 1994 and in 2010, Gilbert described pronunciation as 'an orphan in English programs around the world '.

\section{Purpose of the Study}

The main purpose of the present study is to investigate the most important ways to improve EFL students' pronunciations at Ajloun National University (ANU) .

\section{Questions of the study}

Q1: What are the most frequently used ways to improve English words' pronunciation used by ANU EFL learners?

Q 2: What are the least frequently used ways to improve English words' pronunciation used by ANU EFL learners?

\section{Significance of the Study}

The importance of words' pronunciation awareness has been proved in literature. So it is hoped that the results of the present study may provide the teachers and learners with different kinds of suitable ways that can be implemented inside the EFL classroom and may also help them increase their students' oral proficiency. Moreover, the researchers may investigate other ways that make the speaking skill more purposeful and beneficial

\section{Limitations of the Study}

The findings of this study are limited to the participants of the study at Ajloun National University which is confined to English Language major students. It is also limited to the first semester of the academic year 2017/2018. Therefore, the generalizability of the results of this study is applicable to similar participants only. 


\section{Participants of the Study}

The researcher's chose 20 EFL students (10 males \& 10 females) as participants in this research who studied English language and literature at Ajloun National University.

\section{Instruments of the Study}

In order to investigate the ways used by EFL learners to improve their pronunciations, , a questionnaire was developed. To show the degree of the extent of using these ways, the researchers followed specific scoring system which include five scales 'strongly agree', 'agree', 'no opinion', 'disagree', and 'strongly disagree'. Then the Questionnaire was distributed to the EFL learners in their class to answer them. Upon completion, the researchers collected all answered questionnaires.

\section{Validity and reliability of the Instrument}

In order to measure the validity of the questionnaire, a jury EFL specialists, linguistics, and applied linguistics, were asked to examine it. The researchers took their suggestions into consideration to produce the final form of the questionnaire. After that Pearson correlation was computed to measure the reliability of the tool using TestRetest strategy (Stability index), it was 0.85 . The internal consistency coefficient was also computed using Cronbach Alpha, it was 0.89 .

\section{The questionnaire correcting method}

To give judgments on the degree of acceptance, and according to the relative statistical model means were classified into three levels as follows: Thus we can say that categories less than (3) represent negative view, and categories more than (3) represent positive view. Also, the researchers used the following categories to judge the items estimation:

- Means (1-less than 2.33) low estimation

- Means (2.34-less than 3.66) medium estimation

- Means (3.67-5) high estimation.

\section{The results and discussion of the questions}

This section presents the findings of the study which aims to know the ways used by EFL students to improve English words pronunciation. Also, this chapter includes questions' answers.

\section{Descriptive statistics}

Table (1): Means and standard deviation for ways used by EFL students to improve their words pronunciation used" domain and total means of them $(n=30)$

\begin{tabular}{|c|c|c|c|c|c|}
\hline No & Domain & Mean & $\begin{array}{l}\text { Standard. } \\
\text { Deviation }\end{array}$ & Rank & $\begin{array}{l}\text { Agreement } \\
\text { Degree }\end{array}$ \\
\hline 1 & $\begin{array}{l}\text { Listen to Sounds through lectures, radio or TV shows, } \\
\text { movies) or discussions }\end{array}$ & 4.27 & 0.87 & 3 & High \\
\hline 2 & Make friends with native speakers of English & 4.33 & 0.71 & 1 & High \\
\hline 3 & $\begin{array}{l}\text { share accommodation with an English speaking person or } \\
\text { family }\end{array}$ & 3.90 & 1.12 & 9 & High \\
\hline 4 & $\begin{array}{l}\text { Read loudly from magazines newspapers, and novels for } \\
\text { minutes a day! }\end{array}$ & 3.93 & 0.87 & 8 & High \\
\hline 5 & Watch English language films and movies.. & 4.00 & 1.20 & 6 & High \\
\hline 6 & $\begin{array}{l}\text { Find useful internet sites that teach you English } \\
\text { vocabulary, grammar ...etc }\end{array}$ & 4.30 & 1.06 & 2 & High \\
\hline 7 & Sing along to some favorite songs on radio & 4.03 & 1.03 & 5 & High \\
\hline 8 & $\begin{array}{l}\text { Use social media sites and communications technology in } \\
\text { English. E.g. chatting with your friend in English via } \\
\text { cam, Skype or emailing them in English }\end{array}$ & 4.00 & 1.05 & 6 & High \\
\hline 9 & $\begin{array}{l}\text { Attend Learning workshops on developing speaking } \\
\text { skills such as oral presentations, conversation, etc) }\end{array}$ & 3.77 & 0.90 & 10 & High \\
\hline 10 & Use a good English language Dictionary & 4.17 & 0.95 & 4 & High \\
\hline 11 & $\begin{array}{l}\text { Attend cinemas, plays or other events in English } \\
\text { organized by any English language organizations. }\end{array}$ & 3.53 & 1.25 & 11 & medium \\
\hline \multicolumn{2}{|r|}{ Total Means } & 4.02 & $\mathbf{0 . 5 0}$ & - & High \\
\hline
\end{tabular}


Table (1) shows that the highest means reached (4.33) out of (5) for item (2) "Make friends with native speakers of English" by high agreement degree, then for item (6) "Find internet sites that have vocabulary, grammar, and speaking resources" (means 4.30) by high agreement degree, then for item (1) "Listen to Sounds through lectures, radio or TV shows, movies) or discussions" (means 4.27) by high agreement degree, and the lowest means was (3.53) for item (11) " Attend cinemas, plays or other events in English organized by any English language organizations" by medium agreement degree.

The total means for "improve English words pronunciation used" reached (4.02) by high agreement degree.

The first question: What are the most frequently used to improve English words pronunciation used by ANU EFL students?

To answer this question, frequencies and percentages for highest items of "improve English words pronunciation used", were calculated; table (2) shows that.

Table (2): frequencies and percentage for highest items of for ways used by EFL students to improve their words pronunciation

\begin{tabular}{|c|c|c|c|c|}
\hline $\mathbf{N}$ & Item & Categories & Frequency & percent \\
\hline \multirow[t]{5}{*}{2} & \multirow[t]{5}{*}{ Make friends with native speakers of English } & $\begin{array}{l}\text { Totally } \\
\text { Disagree }\end{array}$ & - & - \\
\hline & & Disagree & - & - \\
\hline & & Neutral & 4 & 13.3 \\
\hline & & Agree & 12 & 40.0 \\
\hline & & Totally Agree & 14 & 46.7 \\
\hline \multirow[t]{5}{*}{6} & \multirow[t]{5}{*}{$\begin{array}{l}\text { Find useful internet sites that teach you English } \\
\text { vocabulary, grammar ...etc }\end{array}$} & $\begin{array}{l}\text { Totally } \\
\text { Disagree }\end{array}$ & 1 & 3.3 \\
\hline & & Disagree & 2 & 6.7 \\
\hline & & Neutral & 1 & 3.3 \\
\hline & & Agree & 9 & 30.0 \\
\hline & & Totally Agree & 17 & 56.7 \\
\hline \multirow[t]{5}{*}{1} & \multirow[t]{5}{*}{$\begin{array}{l}\text { Listen to Sounds through lectures, radio or TV shows, } \\
\text { movies) or discussions }\end{array}$} & $\begin{array}{l}\text { Totally } \\
\text { Disagree }\end{array}$ & - & - \\
\hline & & Disagree & 2 & 6.7 \\
\hline & & Neutral & 2 & 6.7 \\
\hline & & Agree & 12 & 40.0 \\
\hline & & Totally Agree & 14 & 46.7 \\
\hline
\end{tabular}

Table (2) shows that:

- For item (2) "Make friends with native speakers of English", the highest category (Totally Agree) by frequency (14) percentage (46.7\%), then category (Agree) by frequency (12) percentage (40.0\%), but the lowest category (Neutral) by frequency (4) percentage (13.3\%).For item (6) " Find useful internet sites that teach you English vocabulary, grammar ...etc ", the highest category (Totally Agree) by frequency (17) percentage (56.7\%), then category (Agree) by frequency (9) percentage (30\%), but the lowest category (Totally Disagree) and (Neutral) by frequency (1) percentage $(3.3 \%)$.

- For item (1) "Listen to Sounds through lectures, radio or TV shows, movies) or discussions", the highest category (Totally Agree) by frequency (14) percentage (46.7\%), then category (Agree) by frequency (12) percentage (40\%), but the lowest category (Disagree) and (Neutral) by frequency (2) percentage (6.7\%). The findings of the first question showed that the overall degree of that ways used by EFL learners to improve their pronunciation is high. This result highlights the importance of these ways are used by the EFL learners .Those ways should be investigated because they are considered as significant factors in determining the teaching effectively and efficiency of those EFL learners in their classrooms. Jones (2002) indicates that pronunciation teaching ways and methods should address the issues of motivation..

These strategies enable learners to understand, produce and pronounce words and sentences effectively. The learners' responses to most of these items in the questionnaire showed their high positive using different ways toward the learning the correct pronunciation. 
The second question: What are the least frequently used to improve English words pronunciation used by ANU EFL students?

To answer this question, frequencies and percentages for lowest items of "improve English words pronunciation used", were calculated; table (3) shows that.

Table (3): frequencies and percentage for lowest items of for ways used by EFL students to improve their words pronunciation

\begin{tabular}{|c|c|c|c|c|}
\hline $\mathbf{N}$ & Item & Categories & Frequency & percent \\
\hline \multirow{5}{*}{3} & \multirow{5}{*}{$\begin{array}{l}\text { share accommodation with } \\
\text { an English speaking person } \\
\text { or family }\end{array}$} & Totally Disagree & 1 & 3.3 \\
\hline & & Disagree & 3 & 10.0 \\
\hline & & Neutral & 5 & 16.7 \\
\hline & & Agree & 10 & 33.3 \\
\hline & & Totally Agree & 11 & 36.7 \\
\hline \multirow{5}{*}{9} & \multirow{5}{*}{\begin{tabular}{lr}
\multicolumn{3}{l}{ Attend Learning workshops } \\
on developing speaking \\
skills such as \\
presentations, & \\
conversation, etc) &
\end{tabular}} & Totally Disagree & - & - \\
\hline & & Disagree & 4 & 13.3 \\
\hline & & Neutral & 4 & 13.3 \\
\hline & & Agree & 17 & 56.7 \\
\hline & & Totally Agree & 5 & 16.7 \\
\hline \multirow{5}{*}{11} & \multirow{5}{*}{$\begin{array}{l}\text { Attend cinemas, plays or } \\
\text { other events in English } \\
\text { organized by any English } \\
\text { language organizations. }\end{array}$} & Totally Disagree & 3 & 10.0 \\
\hline & & Disagree & 4 & 13.3 \\
\hline & & Neutral & 3 & 10.0 \\
\hline & & Agree & 14 & 46.7 \\
\hline & & Totally Agree & 6 & 20.0 \\
\hline
\end{tabular}

Table (3) shows that:

- For item (3) " share accommodation with an English speaking person or family", the highest category (Totally Agree) by frequency (11) percentage (36.7\%), then category (Agree) by frequency (10) percentage (33.3\%), but the lowest category (Totally Disagree) by frequency (1) percentage (3.3\%).For item (9) " Attend Learning workshops on developing speaking skills such as oral presentations, conversation, etc)", the highest category (Agree) by frequency (17) percentage (56.7\%), then category (Totally Agree) by frequency (5) percentage (16.7\%), but the lowest category (Disagree) and (Neutral) by frequency (4) percentage (13.3\%). For item (11)

" Attend cinemas, plays or other events in English organized by any English language organizations", the highest category (Agree) by frequency (14) percentage (46.7\%), then category (Totally Agree) by frequency (6) percentage (20\%), but the lowest category (Totally Disagree) and (Neutral) by frequency (3) percentage $(10 \%)$.

- The results of this question highlight that these ways are used less than others by our EFL learners, students don't always share accommodation with an English speaking person or family. They often attend Learning workshops on developing speaking skills, such as oral presentations, conversation, etc, or attend cinemas, plays or other events in English organized by any English language organizations.. The results of this question agree with the results of a study by Jaume \& Castellón (2014) who believed that there are many factors toward our students' weakness when being taught pronunciation. One of them is the usefulness of pronunciation instruction and helpful strategies they used that may affect performance .

\section{Conclusion}

Language is originally a mean of communication between people, communication is achieved through speaking and listening before writing and reading. The findings of the study show that The EFL students possess many of the most necessary ways that enable them to learn how to pronounce words correctly. To conclude, the findings of the data showed that the ways most often used by the EFL learners in this study were "making friends with native speakers of English", "Listening to sounds through lectures, radio or TV shows, movies and "improving English words pronunciation used".

However, the least used strategies discovered are 'share accommodation with an English speaking person or family', ' Attend cinemas, plays or other events in English organized by any English language organizations'. 
According to the results of this study, Further researches should be done on the effectiveness of developing and improving the pronunciation of Arabic speakers, pronunciation training should begin early in EFL classroom. In addition, Ministry of education should take into consideration that teaching sound - symbol is a major component in the any training project. English language students shouldn't just restrict their study on academic curricula, they should read books and use social media to learn how to pronounce words effectively.

\section{References}

Bashiruddin, A. (2003). Learning English and learning to teach English: the case of two teachers of English in Pakistan. Unpublished doctorate dissertation, University of Toronto, Canada.

Baxter,B.(1954).Speaking for the Master. London: Collier-Macmillan Limited.

Hassan, E (2014). Pronunciation Problems: A Case Study of English Language Students at Sudan University of Science and Technology. English Language and Literature Studies; Vol. 4, No. 4.31-44

Hamzah ,O and Miko Umehara. (2010). using 'A Shadowing' Technique' to Improve English Pronunciation Deficient Adult Japanese Learners: An Action Research on Expatriate Japanese Adult Learners. THE JOUR AL OF ASIA TEFL . 7,( 2), 199-230

Li, R. (2003). Factors that Chinese Students Believe to Affect Their Oral Fluency. Teaching English In China. Foreign Language Teaching and Research Press. Beijing. 27. 52:23

Ministry of Education. (2006).General Guidelines and General and Specific Outcomes for English Language . Amman. Jordan. Nuria ,M.(2014). Pronunciation and Comprehension of Oral English in the English as a Foreign Language Class: Key Aspects, Students' Perceptions and $\square$ Proposals. Journal of Language Teaching and Research, 5, (2 ). 262-273

Omer ,E and Khan, W (2015). The Pronunciation Problems Faced by Saudi EFL Learners at Secondary Schools. Education and Linguistics. 1, (2).85-99

Pourhosein Gilakjani, A. (2012). A Study of Factors Affecting EFL Learners' English Pronunciation Learning and the Strategies for Instruction. International Journal of Humanities and Social Science 2. 3, 119-128.

Rama, Josephine, Ying, Cheong Choy, Lee, Koh Row and Au Yong LueiLue. (2011). Using Games in English language Learning." http://conference.nie.edu.sg/2007/paper/papers/STU543.pdf

Urrutia, W., \& Vega, E. (2006). Encouraging teenagers to improve speaking skills through games in a Colombian public school. PROFILE Issues in Teachers' Professional Development, 12(2) 